\title{
Binaların Güçlendirme/Yıkım Kararı Sürecindeki Ekonomik Değerlendirme İçin Yeni Bir Yöntem Önerisi: Eğitim Yapıları Örneği ${ }^{* *}$
}

\author{
A. Hakan Mutlu ${ }^{1}$ \\ 'İnşaat ve Emlak Dairesi Başkanlığı / Millî Eğitim Bakanlığı / Ankara, Türkiye (ORCID: 0000-0002-5750-3958)
}

(Konferans Tarihi: 5-7 Mart 2020)

(DOI: $10.31590 /$ josat.araconf7)

ATIF/REFERENCE: Mutlu, A. H. (2020). Binaların Güçlendirme/Yıkım Kararı Sürecindeki Ekonomik Değerlendirme İçin Yeni Bir Yöntem Önerisi: Eğitim Yapıları Örneği. Avrupa Bilim ve Teknoloji Dergisi, (Özel Sayı), 46-56.

Öz

Yürürlükteki yönetmelik hükümleri doğrultusunda deprem güvenliği çalışmaları yapılan bir binanın güçlendirilmesine ya da yıkılmasına karar verilmesi aşamasında her bina için güçlendirme maliyetinin yeniden yapım maliyetine oranında sabit \%40 eşik değerinin kullanıldığ 1 bilinmektedir.

$\mathrm{Bu}$ çalışmada, deprem güvenliği irdelenmiş bir binanın güçlendirilmesi veya yıkılarak yerine yenisinin yapılması hakkında karar verilirken, ilk aşamada, yalnızca sabit \%40 değeri yerine binaların yapım yıllarına göre farklı eşik değerler belirlenmiştir. İkinci aşamada ise, güncel standartlar ve yönetmelikler gereği yapılması zorunlu imalatlar da ekonomik değerlendirme hesaplarına dâhil edilmiştir. Bu iki aşama, tüm binalar için geçerli olmaktadır.

İlk iki aşamadan sonra, deprem güvenliği incelemesi tamamlanmış eğitim yapısı için derslik başına düşen öğrenci sayısına göre ek derslik ihtiyacı olup olmadığı, aynı hizmet bölgesinde yeni yapılacak yatırımlar ve diğer karşılaşılabilecek durumlar değerlendirmeye alınmıştır.

Yukarıda aşamaları özetlenen yeni ekonomik değerlendirme yönteminde, Taşınmaz Değerleme Yöntemi tanımlamaları ile Federal Acil Durum Yönetimi Ajansı (Federal Emergency Management Agency - FEMA) tarafından uygulanan \%50 Kuralı prensiplerinden yararlanılmıştır.

Anahtar Kelimeler: Güçlendirme, yıkım, deprem güvenliği, ekonomik değerlendirme.

\section{Proposal of a New Method for Economic Assessment in the Process of Retrofit / Demolition of Buildings: Example of Educational Structures}

\begin{abstract}
In accordance with the provisions of the current regulation, it is known that a fixed $40 \%$ threshold is used for each building in the ratio of the retrofit cost to the reconstruction cost during the decision to retrofit or demolish a building undergoing earthquake safety studies.

In this study, when it is decided to retrofit or demolish a building which has been examined for earthquake safety, in the first stage, different thresholds are determined according to the construction years of buildings instead of only fixed 40\%. In the second stage, the compulsory productions that have to be made in accordance with current standards and regulations are included in the economic evaluation calculations. These two phases apply to all buildings. After these two stages, whether the need for additional classrooms
\end{abstract}

\footnotetext{
* Bu makale International Conference on Access to Recent Advances in Engineering and Digitalization (ARACONF 2020) de sunulmuştur.
} 
according to the number of students per classroom for the education structure whose earthquake safety survey was completed, new investments to be made in the same service area and other possible situations were evaluated.

In the new economic evaluation method, the stages of which are summarized above, the Real Estate Appraisal Method definitions and the 50\% Rule principles applied by the Federal Emergency Management Agency (FEMA) were utilized.

Keywords: Reinforcement, demolition, earthquake safety, economic evaluation.

\section{Giriș}

Temelde değerleme (veya değer biçme, kıymet takdiri, değer takdiri); taşınmaz ve taşınır mal, gelir ve haklara bilimsel yöntemlere göre değer belirleme veya tahmini tekniğini öğreten bir bilim dalıdır [1]. Değerleme; taşınmaz ve taşınır mallar, taşınmaz projesi, sınırlı ayni haklar, gayri maddi ve kişisel mülklerin değerleri konusunda sağlıklı yargı veya kanaat oluşturmak için yapılan ve sistematik biçimde tamamlanan tespit, sınıflama, analiz ve yorumlama çalışmalarının bütünü olarak da tanımlanabilir. Gayrimenkul değerlemesi ise; taşınmazın belli bir tarihteki imar durumu, konumu zemin ve inşaat yapısı, elde edilen gelir, ulaşım imkânı, altyapı durumu, parselin şekli (boyutu, genişliği ve eğimi gibi), değerini etkileyen bütün unsurlarının dikkate alınarak kıymetinin para cinsinden ifade edilmesi işi olarak tanımlanmaktadır [2].

Genel olarak değerleme uzmanları tarafından incelenen gayrimenkullerin türleri; konut, ticari gayrimenkul, endüstriyel gayrimenkul, tarımsal gayrimenkul ve özel amaçlı gayrimenkul olarak sınıflandırılabilir [3]. Çalışmanın örnek konusu olan eğitim yapıları (okullar), golf alanları ve ibadet alanları ile birlikte “özel amaçlı gayrimenkuller” kapsamında değerlendirilmektedir.

Taşınmaz değerlerini saptamak için pek çok yöntem kullanılsa da temelde üç yöntem vardır. Bunlar: karşılaştırma, gelir ve maliyet yöntemleridir

Değerleme için seçilecek yöntem, değeri saptanacak taşınmazın konumuna ve taşınmaz piyasasının egemen alışkanlıklarına göre belirlenir. Üzerinde yapı bulunan ya da bulunmayan imar parselleri için en açık ve inandırıcı değer saptama, sürüm değerleri yardımı ile olur. Bu nedenle, elde yeter derecede emsal değer bulunduğunda karşılaştırma yöntemi en elverişli yöntemdir.

Taşınmazların değeri, yalnızca ileride getirecekleri gelirlere göre saptanabiliyorsa -örneğin kiralık konut ya da iş yerlerindesürüm bedellerinin bulunması için gelir yönteminin uygulanması yerinde olur.

Fabrika, iş hanı gibi üzerinde yapı bulunan ve kira gelirleri bilinmeyen taşınmazlar için sürüm değeri, kural olarak maliyet yöntemine göre bulunur [4].

Yukarıda özetlenen yöntemlerden görüleceği üzere eğitim yapısının değerlemesinin yapılabilmesi için maliyet yönteminin uygulanmasının gerektiği anlaşılmaktadır. $\mathrm{Bu}$ nedenle, taşınmaz değerlerini belirlemek için kullanılan karşılaştırma ve gelir yöntemleri çalışmanın dışında tutulmuştur.

Maliyet; yeniden üretme maliyeti ve yerine koyma maliyeti olmak üzere kavramsal acıdan iki farklı şekilde düşünülebilir. Yapı ve eklentilerinin maliyet bedellerinin belirlenmesi ile uygun yıpranma oranının seçiminde bu kavramların bilincinde olunmalıdır. Yeniden üretme maliyeti; aynı inşaat malzemeleri, aynı tasarım ve işçilik kalitesi ile orijinal yapının tamamen aynısının üretilmesinde karşılaşılacak maliyettir. Yerine koyma maliyetine ise yapının; modern inşaat malzemeleri, tasarım teknikleri ve işçilik kullanılarak yeniden üretilmesinde karşılaşılır. Yerine koyma kavramında, artık kullanılmayan modası geçmiş inşaat malzemelerinin, tasarım ve işçilik tekniklerinin kullanılması elimine edilerek fonksiyonel eskimenin birçok şekli ortadan kaldırılmaktadır [4].

Amortisman kavramı, maliyet yöntemi kapsamında, gayrimenkulün maruz kaldığı herhangi bir yıpranma etkisini yansıtmak amacıyla, aynı faydaya sahip bir gayrimenkul oluşturmak için katlanılacak tahmini maliyette yapılan düzeltmeleri ifade eder [5].

Amortismanın hesaplanması "Maliyet Yöntemi” içinde önemli bir yere sahiptir. Amortisman hesabı bazı durumlarda kendi içinde birden çok kaleme ayrılabilmekte; dolayısıyla, hesaplanması karmaşık olabilmektedir.

Amortismanın kelime anlamı yavaş yavaş öldürmektir. Admortir kelimesinden türemiştir. Mortir ölmek veya öldürmek anlamına gelir. Ad ise önüne geldiği kelimenin anlamını yavaşlatan bir ön ektir. Öz olarak sabit kıymetlerin hizmet süresi içinde yok edilmesi fikri, amortisman fikridir [6].

Vergi Usul Kanunu'na göre; amortisman, bir işletmede bir yıldan fazla kullanılan ve yıpranmaya, aşınmaya veya kıymetten düşmeye konu olan varlıkların yok edilmesidir. Kullanmayı, yıpranmayı, aşınmayı ve değerden düşmeyi telafi edebilmek için her hesap döneminde gayrimenkuller, gayrimenkul gibi değerlenen iktisadi kıymetler, alet, edevat, mefruşat, demirbaş ve sinema filmlerinin değerinin bir bölümü amortisman olarak ayrılmakta ve işletmenin kârından düşürülmektedir. Kanuni ölçülere göre her hesap döneminin sonunda ilgili mevcutların değerinin bir kısmı indirilerek gider yazılmakta ve amortisman süresinin sonunda değer tamamen itfa edilmiş olmaktadır [7].

Yapıların değerleme günündeki maliyet bedelleri hesaplandıktan sonra yıpranma (amortisman) oranlarının kestirimi gereklidir. Yapıda meydana gelmiş yıpranma, yapının değerleme günündeki maliyet değerinden düşüklüğü ifade eder. Yapının değerleme günündeki maliyet bedeli ise saptanacak değerin üst sınırıdır.

Amortisman tutarının hesabına dair iki farklı yaklaşım bulunmaktadır. Bunlar; doğrusal amortisman ve gözlemlenen durum yöntemleridir.

Bu çalışmada uygulanan Doğrusal Amortisman Yöntemi, yeniden inşa etme maliyetinin ve binanın kalan ekonomik ömrünün bilindiği, değer düşüşünün her yıl sabit bir yüzdeyle ifade edildiği varsayımlarına dayanır. 
Doğrusal amortismana örnekler ülkemizdeki 333, 339 ve 365 sıra No.lu Vergi Usul Kanunu genel tebliğlerinde mevcuttur. 1.1.2004 tarihinden itibaren "amortismana tabi iktisadi kıymetlerin, Maliye Bakanlı̆̆ tarafından faydalı ömürleri dikkate alınarak belirlenecek oranlar üzerinden amortisman yolu ile itfa edilmesi uygulaması"na başlanmasından beri Maliye Bakanlığı kendisine verilen yetkiyi kullanarak bugüne dek yayınladığı;

- 333 Sira No.lu Vergi Usul Kanunu Genel Tebliği,

- 339 Sira No.lu Vergi Usul Kanunu Genel Tebliği,

- 365 Sira No.lu Vergi Usul Kanunu Genel Tebliği,

eklerindeki listelerde amortismana tabi iktisadi kıymetlerin faydalı ömürleri ile amortisman oranlarını belirlemiş̧tir.

Amortismana tabi iktisadi kıymetler listesinin binalar ile ilgili kısmında yer alan; ticari, sınai, zirai ve mesleki işletmelerin idare binaları ile bunların sağlık ve sosyal hizmetlerinde kullandıkları binalar, ticarethane, muayenehane, yazıhane, banka, sigorta, pansiyon, otel, okul, hamam, banyo binaları, tiyatro ve benzeri eğlence yerleri, depo, ardiye, kapalı spor sahaları binaları, spor sahalarındaki tribünler ve benzeri hizmetlere tahsis olunan sair binalar, ikamete mahsus ev, apartman ve emsali binalar için belirtilen faydalı ömürler ve amortisman oranları aşağıda belirtilmiştir. Buna göre:

- Beton, kâgir, demir, çelik binaların faydalı ömrü 50 yıl olmakla beraber, normal amortisman oranı \%2'dir.

- Yarı kâgir, yarı ahşap (Ahşap yapılar üzerine beton ve emsali püskürtmek suretiyle yapılmış binalar dahil.) binaların faydalı ömrü 33 y1l olmakla beraber, normal amortisman oranı $\% 3,03$ 'tür.

- Ahşap, kerpiç binaların faydalı ömrü 20 yıl olmakla beraber, normal amortisman oranı \%5’tir.

$\mathrm{Bu}$ çalışmada, ayrıca, herhangi bir eğitim yapısının güçlendirilmesi veya yıkılması hakkında karar verilmesi aşamasında oluşturulan yeni yöntemde, Federal Acil Durum Yönetimi Ajansı (Federal Emergency Management Agency - FEMA) tarafindan uygulanan \%50 Kuralı prensiplerinden yararlanılmıştır.

Amerika Birleşik Devletleri genelindeki yardım çalışmalarını koordine etme sorumluluğu 1979 yılında kanunla verilmiş olan Federal Acil Durum Yönetimi Ajansı (Federal Emergency Management Agency - FEMA) Yönetmeliklerinde afetten zarar görmüş herhangi bir tesisin onarılması veya yenilenmesi için \%50 kuralının uygulanması öngörülmüştür.

FEMA tarafından uygulanan ve yönetmeliklerinde geçen \%50 Kuralının koşulları ve bu koşullara uygun maliyet seçimleri aşă̆ıda özetlenmiş̧tir:

1. Onarım maliyeti, yenileme maliyetinin \%50'sini geçmiyor, aynı zamanda yapıda yönetmelik ve standartlarda belirtilen zorunlu imalatların yapılması gerekmiyorsa, yalnızca oluşan hasar onarılır.

2. Onarım maliyeti, yenileme maliyetinin $\% 50$ 'sini geçmiyor, ancak yapıda yönetmelik ve standartlarda belirtilen zorunlu imalatların yapılması gerekiyorsa ve toplam maliyet yenileme maliyetinin $\% 50$ 'si ile $\% 100$ 'ü arasında kalıyorsa, hasar onarılır ve yönetmelik ve standartlarda belirtilen zorunlu imalatlar yapılır.

3. Onarım maliyeti, yenileme maliyetinin $\% 50$ 'sini geçmiyor, ancak yapıda yönetmelik ve standartlarda belirtilen zorunlu imalatların yapılması gerekiyorsa ve toplam maliyet yenileme maliyetinin \%100'ünden fazla ise, 2. Maddede belirtilen durum veya yapının yenilenmesi seçilebilir, hangisi seçilirse seçilsin maliyetler yenileme maliyeti ile sınırlı olduğundan uygun maliyet yenileme maliyeti kadar olacaktır.

4. Onarım maliyeti, yenileme maliyetinin $\% 50$ 'sini aşıyorsa, yapı yenilenebilir, başvuru sahibi 2 . Maddede belirtilen durumu da seçebilir, bu durumda yenileme veya onarım maliyetlerinden hangisi düşükse, o uygun maliyet olarak belirlenir.

Her kuralda olduğu gibi \%50 Kuralında da bazı kısıtlamalar ve kabuller bulunmaktadır.

1. Kuralın uygulanması, tesisin nasıl inşa edildiğine bağlıdır. Örneğin bir okul kampüsünde her bina için ayrı ayrı uygulanır.

2. Kural uygulanırken, yapının her elemanı ayrı tutulmalıdır. Örneğin afetten zarar görmüş bir binada pencereleri ayırmak mümkün değildir ve pencerelerin \%51'i tahrip olmuşsa tüm pencerelerin değiştirilmesinin gerekli olduğu sonucuna varılır.

3. Kolayca ayrılabilen birden fazla bileşenden oluşan bir sistem varsa, $\% 50$ Kuralının sistemin bütününe değil tek tek bileşenlerine uygulanması daha pratiktir. Örneğin kanalizasyon sisteminin bir bileşeni kuyudan kuyuya kadar olan bir bölümü olabilir.

4. Hesaplamalarda, kesrin payı, afet sonucu oluşan onarım maliyeti ve zarar görmüş bina elemanları için geçerli olan yönetmelik ve standartlar gereği yapılması zorunlu imalatları kapsamaktadır.

5. Hasar görmeyen elemanlar için geçerli olan yönetmelik ve standartlar gereği yapılması zorunlu imalatlar, tasarım güncellemeleri, saha çalışması, proje yönetimi maliyeti ve tehlike azaltma maliyeti kesrin pay kısmında yer alamaz.

6. Kesrin paydası ise yeniden yapım maliyetini içermektedir. Yeniden yapım maliyeti ise yapının afet öncesi duruma getirilmesi esasında mevcut yönetmelik ve standartlara uygun olarak yapıyı değiştirme maliyeti şeklinde tanımlanmaktadır. Mevcut yönetmelik, sismik direnç, mekanik veya elektriksel sistemler gibi yapısal elemanlar veya bir yapının büyüklüğü ile ilgili olabilir. Örneğin mevcut yönetmelik, bir okulda öğrenci başına daha fazla miktarda alan veya herhangi bir köprüdeki yolların daha genişşseritleri gerektirebilir. Boyutla ilgili bir yönetmeliğin kullanılması, yenilenen yapının mevcut yapı ile aynı kapasiteye sahip olması ile sınırlıdır. Okul öğrenci kapasitesinin artırılması paydaya dâhil edilemez. 
7. Ulusal Tarihi Yerler Sicilinde listelenen yapılar için \%50 Kuralı uygulanmaz. Mevcut yönetmelik veya standartlar tarihi yapının belirli bir şekilde restore edilmesini gerektiriyorsa ve diğer seçeneklere izin vermiyorsa, restorasyon (yenileme) maliyeti yeniden yapım maliyetini aşabilir [8].

Bu kural, FEMA tarafından, yalnızca, afet sonrası zararları karşılama kapsamında uygulandığı anlaşılmaktadır. Ancak prensipler incelendiğinde, \%50 Kuralının, güçlendirme maliyeti / yeniden yapım maliyetinin hesaplandığı afet öncesi çalışmalarına da uyarlanabilir olduğu görülecektir.

Bununla birlikte ülkemizde Zorunlu Deprem Sigortası edindirme, uygulama ve yönetimi faaliyetlerinden sorumlu tüzel kimlikli bir kamu kuruluşu olan Doğal Afet Sigortaları Kurumu (DASK) ise 2000 yılında kurulmuştur. DASK, Zorunlu Deprem Sigortası ile depremin ve deprem sonucu meydana gelen yangın, infilak, tsunami ve yer kaymasının doğrudan neden olacağı maddi zararları, poliçede belirtilmiş limitler dâhilinde nakit olarak karşılamaktadır [9].

Enkaz kaldırma masrafları, kâr kaybı, iş durması, kira mahrumiyeti, alternatif ikametgâh ve işyeri masrafları, mali sorumluluklar ve benzeri başkaca ileri sürülebilecek diğer bütün dolaylı zararlar, her türlü taşınır mal, eşya ve benzerleri, tüm bedeni zararlar ve vefat, manevi tazminat talepleri, deprem ve deprem sonucu oluşan yangın, infilak, tsunami veya yer kaymasının dışında kalan hasarlar ve depremden bağımsız olarak, binanın kendi kusurlu yapısı nedeniyle zamanla oluşmuş zararlar teminat kapsamı dışında kalmaktadır.

Her yıl inşaat maliyetlerindeki artışa göre belirlenen teminat tutarı 7 Eylül 2019 tarihinden itibaren tüm yapı tipleri için 215.000.-TL olarak tespit edilmiştir. Azami teminat tutarı tespit edilirken, yıkılan meskenin yeniden inşa edilmesinin maliyeti (arsa değeri hariç) dikkate alınır. Sigortalının teminat tutarı (sigorta bedeli) -azami teminat tutarın geçmemesi koşuluyla- meskenlerinin büyüklüğüne ve yapı tarzına göre belirlenmektedir. Eğer meskenin değeri DASK tarafından verilen azami teminat tutarını aşıyorsa, sigortalı isteğe bağlı olarak, aşan kısım için sigorta şirketlerinden ek teminat alınabilir. Bunun için özel sigorta şirketlerinden konut sigortanızın olması gereklidir.

DASK kapsamına belediye sınırları içinde kalan meskenler girmektedir.

6305 sayılı Afet Sigortaları Kanunu gereğince, aşağıda tanımlanmış binalar güvence altına alınır:

- Tapuya kayitlı ve özel mülkiyete tabi taşınmazlar üzerinde mesken olarak inşa edilmiş binalar,

- 634 sayılı Kat Mülkiyeti Kanunu kapsamındaki bağımsız bölümler,

- Bu binaların içinde yer alan ve ticarethane, büro ve benzeri amaçlarla kullanılan bağımsız bölümler,

- Doğal afetler nedeniyle devlet tarafından yaptırılan veya verilen kredi ile yapılan meskenler.

Zorunlu Deprem Sigortası ayrıca yukarıdaki koşullara uyan;

- Kat irtifakı tesis edilmiş binalar,

- Tapuda henüz cins tashihi yapılmamış ve tapu kütüğünde vasfı "arsa vs." olarak görünen binalar,

- Tapu tahsisi henüz yapılmamış kooperatif evleri,

için de geçerlidir.

Zorunlu Deprem Sigortası kapsamı dışında kalan bina türleri ise aşağıda sıralanmıştır:

- 9.11.1983 tarihli ve 2946 sayılı Kamu Konutları Kanununa tâbi olan veya kamu hizmet binası olarak kullanılan binalar ve bağımsız bölümler,

- Köy nüfusuna kayıtlı ve köyde sürekli oturanlarca köy yerleşik alanları ve civarında ve mezralarda yapılan binalar,

- Tamamı ticari veya sınai amaçla kullanılan binalar,

- Projesi bulunmayan ve mühendislik hizmeti görmemiş binalar,

- Taşıyıcı sistemi olumsuz yönde etkileyecek şekilde tadil edildiği veya zayıflatıldığı tespit edilen binalar,

- Taşıyıcı sistemi olumsuz yönde etkileyecek şekilde ilgili mevzuata ve projeye aykırı olarak inşa edilen binalar,

- Yetkili kamu kurumları tarafindan yıkılmasına karar verilen binalar ile mesken olarak kullanıma uygun olmayan, bakımsız, harap veya metruk binalar."

Yukarıda da açıklandığı üzere eğitim yapıları kamu hizmet binası statüsünde yer aldığından deprem sigortası kapsamında yer almamaktadır.

\section{Materyal ve Metot}

Mevcut bir binanın yürürlükteki yönetmelik hükümleri çerçevesinde deprem güvenliğinin belirlenmesi aşamasında yapı güvenliği ile ilgili bir görüş ve karar oluşturulması gerekmektedir. Karar aşağıda verilen seçeneklerden biri olabilir:

- Yeterli yapı güvenliği vardır, onarım ve/veya güçlendirmeye gerek yoktur. 
- Yapı, kullanım sınırlanarak, hiçbir müdahale yapılmadan kullanılabilir.

- Onarım/güçlendirme ile bina gereken yapı güvenliğine kavuşturulabilir.

- Onarım/güçlendirme ekonomik ve pratik açıdan geçerli bir çözüm değildir, yapının tümü veya bir bölümü yıkılmalıdır [10].

Çalışmanın konusu olan son iki seçenekte belirtilen onarım/güçlendirme veya yıkım kararı için yukarıda tanımı verilen yeniden yapım maliyeti göz önüne alınmaktadır. Hesaplamalarda genellikle hazırlanan güçlendirme projesi kapsamında belirlenen maliyetin söz konusu binanın yeniden yapım maliyetine oranlanması sonucu ortaya çıkan değerin 0,40 'tan (\%40) düşük veya yüksek çıkmasına göre değerlendirme yapılmaktadır [11]. Belirtilen $\% 40$ değerinin genel bir teamül olarak kullanıldığı ve güçlendirme ya da yıkım kararını etkileyen diğer faktörlerin neler olabileceği Mutlu A.H. (2015) tarafından yapılan çalışmada açıklanmaktadır.

Arıkan, M. ve arkadaşları (2005) tarafından yapılan çalışmada ise 40 yaşında ve 10 yaşındaki binalar için kritik maliyet oranı sırasıyla \% 25 ve \% 67 olarak hesaplanmıştır. Yani 40 yaşında bir bina için yeniden yapım maliyetinin $\% 25$ 'inden fazla güçlendirme harcaması yapılmaması önerilirken, 10 yaşındaki bir bina için de yeniden yapım maliyetinin \% 67'sine kadar güçlendirme harcaması yapılabileceği belirtilmiştir [12].

$\mathrm{Bu}$ çalışmada ise; teknik açıdan güçlendirilmeye uygun bulunan bina hakkında karar oluşturabilmek için sınırlı bir ekonomik değerlendirme olarak görülen \% 40 'lık teamül değerinin kullanılmasının yerine; yapıya özel, güncel yönetmelik ve standartlar kapsamında değerlendirilebilen -eğitim yapıları için yatırım planlamaların da kapsayan- yeni bir ekonomik değerlendirme yöntemi oluşturulmuştur.

Yöntem için; Gayrimenkul Değerlemede kullanılan yapının yeniden yapım maliyeti ve yerine koyma maliyeti tanımlarından, Vergi Usul Kanununa göre hesaplanan amortisman (yıpranma) oranlarından ve Federal Acil Durum Yönetimi Ajansı (Federal Emergency Management Agency - FEMA) tarafindan uygulanan \%50 Kuralı genel prensiplerinden yararlanılmıştır.

Mutlu A.H. (2015) tarafından yapılan çalışmada; güçlendirme veya yıkım kararı için onarım/güçlendirme maliyetinin yeniden yapım maliyetine oranının bina yaşı ile bağlantı kurularak değerlendirildiği bir yaklaşım ele alınmıştır:

$\mathrm{C}_{\mathrm{R}} \leq 0,80 \cdot \mathrm{C}_{\mathrm{N}}\left[\left(\mathrm{L}_{\mathrm{D}}-\mathrm{L}_{\mathrm{P}}\right) / \mathrm{L}_{\mathrm{D}}\right]$

Burada:

$\mathrm{C}_{\mathrm{R}}$ : Güçlendirme maliyeti, (GM)

$\mathrm{C}_{\mathrm{N}}$ : Yeniden yapım maliyeti, (YYM)

$\mathrm{L}_{\mathrm{D}}$ : Mevcut yapı için tasarlanan yapı ömrü (YÖ),

LP: Mevcut yapının yaşı (MYY).

Menşeine ulaşılamayan Eşitlik (1)'e göre; ekonomik ömrü 50 yıl olarak kabul edilen ve yarı ömrünü tamamlamış 25 yıllık bir binanın güçlendirme maliyetinin yeniden yapım maliyetine oranının $\% 40$ olarak hesaplandığı belirlenmiştir. Yine aynı eşitliğe göre; örneğin 10 yaşında bir binanın maliyet oranının \% 45 olarak hesaplanması durumunda ekonomik açıdan yıkılmaması gerektiği, 40 yaşında bir binanın ise maliyet oranının \% 25 olarak hesaplanması durumunda dahi ekonomik açıdan yıkılabilir olduğu vurgulanmaktadır.

Eşitlik (1)'de $\left\{C_{N} \cdot\left[\left(L_{D}-L_{P}\right) / L_{D}\right]\right\}$ ifadesi, binanın yıpranma payı dikkate alınarak hesaplanan yapının güncel değeri (YGD) olarak ortaya çıkacaktır. Çalışmanın geri kalan kısmında simgelerde birliğin sağlanması açısından binanın onarım güçlendirme maliyeti $\left(C_{R}\right)$ yerine $(G M)$, binanın yeniden yapım maliyeti $\left(C_{N}\right)$ yerine $(Y Y M)$, mevcut yapı için tasarlanan yapı ömrü $\left(L_{D}\right)$ yerine (YÖ) ve mevcut yapının yaşı $\left(L_{P}\right)$ ise (MYY) simgesi ile gösterilecektir. Buna göre:

$\mathrm{YGD}=[(\mathrm{YÖ}-\mathrm{MYY}) / \mathrm{YÖ}] \times \mathrm{YYM}$

Burada:

YGD : Yapının güncel değeri,

YYM : Yeniden yapım maliyeti.

Ülkemizde yapım yılı, kullanım amacı, standartlar ve yönetmelikler gereği yapılması zorunlu imalatlarının olup olmadığı dikkate alınmadan uygulanan \% 40 teamülü yerine öncelikle yapının yaşına göre yıpranma payı düşülen yapının güncel değeri üzerinden bir oran bulunması gerektiği tartışılmaya değer bulunmaktadır. Bu oran aşağıdaki eşitlikte verilmiştir:

$\mathrm{AGD}=1-(\mathrm{YYM}-\mathrm{YGD}) / \mathrm{YYM}$

Burada:

AGD : Güçlendirme maliyetinin yeniden yapım maliyetine oranını aşmaması gereken değer,

YYM : Yeniden yapım maliyeti. 
YGD : Yapının güncel değeri.

Eşitlik (3)'te hesaplanan "Aşılmaması Gereken Değer (AGD)" mevcut yapının yaşı (MYY) ve tasarlanan yapı ömrü (YÖ) değişkenleri kullanılarak hesaplanabilir ya da yapının güncel değerinin yüzdesi olarak alınabilir (Eşitlik 4) ve (Eşitlik 5).

$$
\begin{aligned}
& \mathrm{AGD}=(\mathrm{YO}-\mathrm{MYY}) / \mathrm{YO} \\
& \mathrm{AGD}=\mathrm{YGD} / 100
\end{aligned}
$$

Eşitlik $(3,4,5)$ 'te hesaplanan değer, hâlihazırda teamül olarak kullanılan \% 40 sabit oran yerine geçecek ve binanın yapım yılına göre değişen eşik değer olacaktır. Buna göre ilk aşamada;

- $(\mathrm{GM} / \mathrm{YYM}) \leq \mathrm{AGD}$ ise yapı güçlendirilebilir,

- $\quad(\mathrm{GM} / \mathrm{YYM})>$ AGD ise yapı hakkında yıkım kararı alınabilir şeklinde yorumlanabilmektedir.

FEMA tarafindan uygulanan "\%50 Kuralı" prensipleri ile benzer biçimde; ilk aşamada güçlendirme kararı çıkan binalar için yöntemin ikinci aşama hesaplamalarına geçilirken, yıkım kararı kesin sonuç niteliği taşımaktadır.

Yeni yöntem önerisinin ilk aşamasında yapılan hesaplamalarda (GM / YYM) $\leq$ AGD sonucuna ulaşılan binalar için, ikinci aşamada, binanın güncel yönetmelik ve standartlara uygun olmayan, eksik, zorunlu imalatlarının maliyetine ihtiyaç duyulmaktadır. Bu durum FEMA tarafindan uygulanan \%50 Kuralı şartlarının ikinci maddesinde de yer almaktadır. Söz konusu maddede; onarım maliyetinin yenileme maliyetinin \%50'sini geçmemesi şartıyla, onarım maliyeti ile yönetmelik ve standartlarda belirtilen zorunlu imalatların maliyetleri (ZIM) toplamının, yeniden yapım maliyetinin \%50'si ile \%100'ü arasında olması durumunda afet kaynaklı onarımın yapılabilir olduğundan bahsetmektedir. FEMA tarafindan konulan bu prensibin oluşturulan yönteme de uyarlanabildiğ belirlenmiş̧tir. Örneğin 2 Mayıs 2007 tarihinde Resmi Gazetede yayımlanarak yürürlüğe giren Enerji Verimliliği Kanunundan önce yapılmış bir eğitim yapısının (veya herhangi bir resmi kurum binasının) kanun hükümleri doğrultusunda eksik imalatlara ihtiyacı olduğu -örneğin uygun dış cephe 1sı yalıtımı- karş̧laşılan bir durumdur. Diğer yandan binanın yapım tarihinden sonra yürürlükteki kanunlar, yönetmelikler güncellenmiş olabileceğinden yapının -örneğin erişilebilirlik ile ilgili düzenlemelerden dolayı engelli asansörü, engelli rampası, engelli WC gibi- imalatlara ihtiyacı olabilmektedir. Örnek olarak eğitim yapılarını konu alan bu çalışmada FEMA tarafindan uygulanan $\% 50$ oranı yerine, alt limit olarak, güçlendirme maliyetinin yeniden yapım maliyetine oranını aşmaması gereken değer (AGD) esas alınmış, üst limit ise \%100 olarak aynı kalmıştır. Buna göre;

- $\mathrm{AGD} \leq(\mathrm{GM}+\mathrm{ZIM}) / \mathrm{YYM} \leq \% 100$ ise yapı güçlendirilebilir, aynı zamanda yönetmelik ve standartlarda belirtilen zorunlu imalatlar yapılabilir,

- $(\mathrm{GM}+\mathrm{ZIM}) / \mathrm{YYM}>\% 100$ ise yapı hakkında yıkım kararı alınabilir şeklinde yorumlanabilir.

Yukarıda açıklanan iki aşama bina türünde olan her yapı için uygulanabilir niteliktedir.

Millî Eğitim Bakanlığı Strateji Geliştirme Başkanlığı'nın 2018-2019 verilerine göre [13], özel okullar ve açık öğretim okulları hariç olmak üzere, ülkemizde 18.108.860 öğrencinin eğitim-öğretim gördüğü, 1.077.307 öğretmenin hizmet verdiği, toplam 706.015 derslik (66.849 okul) bulunmaktadır. Eğitim ortamlarının kalitesinin artırılması, günümüz teknolojisine uygun eğitim yapılarının ihtiyacı, derslik başına düşen öğrenci sayısının düşürülmesi ve her geçen gün artan nüfus nedeniyle Bakanlıkça her yıl binlerce yeni derslik yapımı gerçekleştirilmektedir. Yeni yapılan dersliklerin yanında, ayrıca, deprem güvenliği belirlenen okulların bir kısmının güçlendirilmesi veya bir kısmının da yıkılıp yerine yenisinin yapılması gerekmektedir. Bu aşamada planlamanın doğru ve zamanında yapılması büyük önem arz etmektedir.

Derslik ihtiyacı doğrultusunda yeni okul yapımı ile deprem güvenliği belirlenen okulların güçlendirilmesi veya yıkılıp yerine yenisinin yapılması işlerinin birbirinden bağımsız olarak planlanması mümkün değildir. Her yıl yüzlerce okulun eğitim öğretim hizmetine sunulmasının maddi zorluğunun yanında, ayrıca, özellikle büyük şehirlerdeki arsa problemleri planlamayı daha da zor hale getirmektedir. Bu nedenle, deprem güvenliği belirlenen eğitim yapılarının güçlendirme veya yıkılıp yerine yenisinin yapılmas kararının verilmesinde ekonomik değerlendirmenin sadece \%40'lık teamül değerinin kullanılarak uygulanmasının yeterli olamayacağı, kararın aynı zamanda eğitim kurumu yatırımları planlanmasının içinde değerlendirilmesinin gerektiği açıktır.

Deprem güvenliği belirlenen bir eğitim yapısının güçlendirilmesi veya yıkılmasına karar verilebilmesi için aşağıdaki soruların yanitlanması gerekmektedir:

1. Eğitim yapısı teknik açıdan güçlendirilmeye uygun mu?

2. Teknik açıdan güçlendirilmeye uygun yapının yıpranma (amortisman) bedeli düşüldüğünde güncel değeri ne kadardır?

3. Deprem güvenliği belirlenen eğitim yapısının güncel yönetmelik ve standartlara göre yapılması zorunlu imalatlara gereksinimi var mı? (Örneğin; enerji verimliliği kapsamında dış cephe yalıııı, engelli asansörü ya da rampası, engelli WC, yangın merdiveni vs.)

4. Eğitim yapısının mevcut haliyle ve/veya yakın gelecekte derslik ihtiyacı var mı?

5. Eğitim yapısının bulunduğu arsa yeni ek derslik yapılması için yeterli büyüklükte mi? 


\section{Eğitim yapısının hizmet alanı içinde yeni yatırım planlaması mevcut mu?}

Yukarıdaki soruların yanıtlarının arandığı yalnızca eğitim yapılarının irdelendiği üçüncü aşamada: mevcut okulun derslik ihtiyacı ile aynı hizmet bölgesinde aynı tür -ilkokul, ortaokul, lise, vb.- yatırımların planlanması, güçlendirme veya yıkım kararı ile birlikte değerlendirilmektedir. FEMA tarafından uygulanan \%50 Kuralında her ne kadar öğrenci sayısının artması ve benzeri nedenlerle kapasite artırımına gidilmesi hesapların dışında tutulmuşsa da, ülkemizde her yıl derslik ihtiyacının artması ve çağın gereksinimlerine uygun okul binası gereksinimi nedeniyle ek derslik bina maliyetinin de karara etki eden önemli bir parametre olduğu düşünülmektedir.

Yukarıda da belirtildiği üzere güçlendirme veya yeniden yapım karar sürecinin yeni yatırımlarla ilişkilendirilmesi -bir başka söylemle yeni yatırımlarla bütünleşik olması- Millî Eğitim Bakanlığı'nın yatırım ödeneklerinin verimli, etkin ve planlı harcanmasına katkı sağlayacaktır. Bu aşamada, güçlendirme maliyetine, güncel yönetmelik ve standartlara uygun olmayan eksik zorunlu imalatların maliyeti ile birlikte genel tabiri ile ek derslik maliyeti (EDM) eklenmiştir.

Derslik başına düşen öğrenci sayısını azaltmak ya da artan öğrenci sayısı ile birlikte derslik ihtiyacını karşılamak amacıyla, mevcut okulun bahçesine Ek Derslik Binası yapılmaktadır. Bina yapımının mümkün olmadığı durumlarda da aynı hizmet bölgesinde yeni bir arsaya ek derslik ihtiyacının da karşılandığı yeni bir okul yatırımı planlanmaktadır. Ancak, mevcut okul bahçesinde ek derslik binası için yeterli alanın bulunmaması ve/veya -özellikle büyükşehirlerde- yeni yatırım planlaması için gereken arsanın temin edilememesi ya da yüksek kamulaştırma bedelleri ödenmesi zorunda kalınması durumunda ise konunun farklı değerlendirilmesi gerekmektedir.

Mevcut bir okulun bahçesine ek derslik binası yapılması yerine, mevcut binanın yıkılarak, ek derslik ihtiyacının da karşılandı̆̆ı, güncel standartlar ve yönetmeliklere uygun yeni bir okul binası yapılması gerekebilmektedir. Ancak, sadece güçlendirme maliyetinin yeniden yapım maliyetine oranı \%40’1 geçmediği için bunu uygulamak zorlaşmaktadır. Burada amaç, güçlendirilebilen binayı yıkarak yerine yenisinin yapılmasını kolaylaştırmak değildir ve olmamalıdır. Asıl amaç, güncel deprem yönetmeliği şartlarını taşımayan teknik olarak güçlendirilebilen- bir binanın depreme karşı güvenli hale getirilmesi için yüzeysel olarak yapılan ekonomik değerlendirmenin daha geniş kapsama kavuşturulmasının sağlanmasıdır.

Bu aşamada, yukarıda tanımı verilen Yerine Koyma Maliyetinin (YKM); güçlendirme maliyeti, yönetmelik ve standartlarda belirtilen zorunlu imalatların maliyeti ve ek derslik maliyetinin toplamı ile karşılaştırılması gerekmektedir:

- $\quad(\mathrm{GM}+\mathrm{ZIM}+\mathrm{EDM}) / \mathrm{YKM} \leq \% 100$ ise mevcut binanın güçlendirilmesi, yönetmelik ve standartlarda belirtilen zorunlu imalatların yapılması ve arsa büyüklüğü uygunsa derslik ihtiyacı kadar ek derslik yapılması daha uygun olacaktır. Mevcut binanın bulunduğu arsa büyüklüğü ek derslik yapımına uygun değilse aynı hizmet bölgesinde yeni yatırım planlanması gerekecektir.

- $\quad(\mathrm{GM}+\mathrm{ZIM}+\mathrm{EDM}) / \mathrm{YKM}>\% 100$ ise eğitim yapısının yıkılıp yerine yenisinin yapılması daha uygun olacaktır. Ancak bu durum tek başına değerlendirilmemelidir. Deprem güvenliği belirlenen eğitim yapısı ile aynı hizmet bölgesinde mevcut veya kısa vadede planlanacak yeni yatırımlarla birlikte incelenmeli, tüm maliyetler hesaplandıktan sonra kesin karara ulaşılmalıdır. Aşağıda olası maliyet seçenekleri gösterilmiştir.

1. Mevcut okul güçlendirilebilir, yönetmelik ve standartlarda belirtilen zorunlu imalatlar yapılabilir, ihtiyaç varsa ek derslik binası inşa edilebilir ve aynı hizmet bölgesinde aynı türde yeni okul binası $\left(\mathrm{YO}_{1}\right)$ yapılabilir. Bu durumda toplam maliyet $\left(\Sigma \mathrm{M}_{1}\right)$;

$$
\Sigma \mathrm{M}_{1}=\mathrm{GM}+\mathrm{ZIM}+\mathrm{EDM}+\mathrm{YO}_{1} \mathrm{M} \text { olacaktır. }
$$

2. Mevcut okul güçlendirilebilir, yönetmelik ve standartlarda belirtilen zorunlu imalatlar yapılabilir, aynı hizmet bölgesinde aynı türde yeni okul mevcut okul binası için ihtiyaç duyulan ek derslik sayısı eklenerek yeni okul binası $\left(\mathrm{YO}_{2}\right)$ yapılabilir. Bu durumda toplam maliyet $\left(\Sigma \mathrm{M}_{2}\right)$;

$$
\Sigma \mathrm{M}_{2}=\mathrm{GM}+\mathrm{ZIM}+\mathrm{YO}_{2} \mathrm{M} \text { olacaktır. }
$$

3. Mevcut okul yıkılabilir, ek derslik ihtiyacının da karşılandığı yeni okul (yerine koyma maliyeti YKM 1 ) yapılabilir, aynı hizmet bölgesinde aynı türde yeni okul binası $\left(\mathrm{YO}_{1}\right)$ inşa edilebilir. Bu durumda toplam maliyet $\left(\Sigma \mathrm{M}_{3}\right)$;

$\Sigma \mathrm{M}_{3}=\mathrm{YKM}_{1}+\mathrm{YO}_{1} \mathrm{M}$ olacaktır.

4. Mevcut okul yıkılabilir, mevcut arsa ile yeni yatırım alınacak arsalardan hangisi uygun ise onun üzerine tüm ihtiyacı karşılayacak tek bir okul $\left(\mathrm{YKM}_{2}\right)$ yapılabilir. Bu durumda toplam maliyet $\left(\Sigma \mathrm{M}_{4}\right)$;

$\Sigma \mathrm{M}_{4}=\mathrm{YKM}_{2}$ olacaktır.

Yalnızca maliyet değerlendirmesine ihtiyaç duyulduğunda, yukarıda belirlenen toplam maliyetler karşılaştırılarak mevcut okul binası ve yeni yatırımla ilgili uygun karar alınabilecektir.

Bu çalışmada, oluşabilecek tüm olasılıklar örneklendirilmemiş, uygulanması önerilen yeni yöntemin prensipleri vurgulanmıştır. Örneğin deprem güvenliği belirlenen birden fazla okul binasının aynı hizmet bölgesinde planlanan bir veya daha fazla yatırımla birlikte değerlendirilmesi gerektiğinde yöntemin prensiplerinin karara yol göstereceği düşünülmüştür.

$\mathrm{Bu}$ yöntemde eğitim yapısının bulunduğu arsalar, genellikle Hazine arazileri olarak kabul edilerek arsa değeri matematiksel hesaplamalara dâhil edilmemiştir. Ancak, mevcut eğitim yapısının güçlendirilmesi yerine yıkılarak -ihtiyaç varsa- yerine derslik sayısı arttırılmış yeni bir eğitim yapısı inşa edilmesi durumunda, aynı hizmet bölgesindeki bir arsaya aynı türde yeni bir okul yapımından 
vazgeçilebilecek ya da farklı türde bir okul ihtiyacı karşılanabilecek olduğundan kamuya ait olan Hazine arazileri de bu yöntem sayesinde etkin, verimli ve ihtiyaca yönelik olarak kullanılmış olacaktır.

\section{Araştırma Sonuçları ve Tartışma}

Bu bölümde, deprem güvenliği belirlendiği varsayılan dört okul binası örnek olarak alınacak ve yukarıda detayları açıklanan yeni yöntem önerisine göre irdelenecek ve sonuçları tartışmaya sunulacaktır.

Yeni önerilen yöntemin prensiplerinin örneklendirilmesi amaçlandığından maddi değerler yerine birim değerlerden ve oranlardan yararlanılmıştır.

24.08.2016 tarihinde Millî Eğitim Bakanlı̆̆ İnşaat ve Emlak Dairesi Başkanlığının sitesinde yayınlanan "Bakanlığımıza Ait Yeni Projeler" [14] başlıklı bölümdeki 8,12,16, 24 ve 32 derslikli lise projelerinin: proje numaraları, derslik sayıları, öğrenci kapasiteleri ve toplam inşaat alanları Tablo 1'de gösterilmiştir.

Tablo 1. MEB Lise Tip Projeleri (2014 yllinda yayınlanan)

\begin{tabular}{|l|c|c|c|}
\hline Proje Numarası & $\begin{array}{c}\text { Derslik } \\
\text { Sayısı }\end{array}$ & $\begin{array}{c}\text { Öğrenci } \\
\text { Kapasitesi }\end{array}$ & $\begin{array}{c}\text { Toplam İnşaat } \\
\text { Alanı } \mathbf{( m}^{\mathbf{2}}\end{array}$ \\
\hline MEB.2014.08.LI & 8 & 240 & 3.544 \\
\hline MEB.2014.12.LI & 12 & 360 & 3.901 \\
\hline MEB.2014.16.LI & 16 & 480 & 5.372 \\
\hline MEB.2014.24.LI & 24 & 720 & 6.059 \\
\hline MEB.2014.32.LI & 32 & 960 & 7.759 \\
\hline
\end{tabular}

Bakanlık tarafından ihtiyaç programlarına göre hazırlanan/hazırlatılan tip projelerin -kullanılan malzemeler, yapım yöntemleri ve inşaat kaliteleri aynı olması kabulü ile toplam inşaat alanları aynı birim maliyetle çarpılacağından- toplam inşaat alanları esas alınarak birbirlerine göre yaklaşık olarak hesaplanan maliyet oranları Tablo 2'de gösterilmiştir.

Tablo 2. Toplam inşaat alanlarına göre maliyet oranlart

\begin{tabular}{|c|c|c|c|c|c|}
\hline $\begin{array}{c}\text { Derslik } \\
\text { Sayısı }\end{array}$ & $\begin{array}{c}\mathbf{8} \\
\text { Derslik }\end{array}$ & $\begin{array}{c}\mathbf{1 2} \\
\text { Derslik }\end{array}$ & $\begin{array}{c}\mathbf{1 6} \\
\text { Derslik }\end{array}$ & $\begin{array}{c}\mathbf{2 4} \\
\text { Derslik }\end{array}$ & $\begin{array}{c}\mathbf{3 2} \\
\text { Derslik }\end{array}$ \\
\hline 8 Derslik & 1,00 & 0,91 & 0,66 & 0,58 & 0,46 \\
\hline 12 Derslik & 1,10 & 1,00 & 0,73 & 0,64 & 0,50 \\
\hline 16 Derslik & 1,52 & 1,38 & 1,00 & 0,89 & 0,69 \\
\hline 24 Derslik & 1,71 & 1,55 & 1,13 & 1,00 & 0,78 \\
\hline 32 Derslik & 2,19 & 1,99 & 1,44 & 1,28 & 1,28 \\
\hline
\end{tabular}

Tablo 2'den de görüleceği üzere; örneğin 24 derslikli bir okulun yapım maliyeti 100 birim kabul edildiğinde, 32 derslikli bir okul yapımı 128 birim maliyete, 12 derslikli okul yapımı ise 64 birim maliyete eşit olacaktır.

Tablo 3. Örnek Olarak Seçilen Okullar Hakkında \%40 Teamülüne Göre Son Karar Tablosu

\begin{tabular}{|c|c|c|c|c|}
\hline Okulun Özellikleri & A & B & C & D \\
\hline Okul Türü & Lise & Lise & Lise & Lise \\
\hline Derslik Sayısı & 16 & 16 & 16 & 16 \\
\hline Öğrenci Kapasitesi & 480 & 480 & 480 & 480 \\
\hline Toplam İnşaat Alanı $\left(\mathrm{m}^{2}\right)$ & 5.372 & 5.372 & 5.372 & 5.372 \\
\hline Güçlendirme Maliyeti (birim) & 41 & 48 & 38 & 27 \\
\hline Yeniden Yapım Maliyeti (YYM) & 100 & 100 & 100 & 100 \\
\hline Güçlendirme Maliyeti / Yeniden Yap1m Maliyeti & $\% 41$ & $\% 48$ & $\% 38$ & $\% 27$ \\
\hline SON KARAR & $*$ & $*$ & $* *$ & $* *$ \\
\hline
\end{tabular}

* Binanın yıkımına karar verilebilir.

** Binanın güçlendirilmesine karar verilebilir.

Tablo 3'te: okul türü, derslik sayısı, öğrenci kapasitesi, toplam inşaat alanı ve yıkılması durumunda yeniden yapım maliyeti aynı olan, ancak güçlendirme maliyetlerinin yeniden yapım maliyetine oranları sırasıyla \%41, \%48, \%38 ve \%27 olarak belirlenen A, B, C ve D okulları görülmektedir.

Teamül olarak kullanılan -her bina için sabit- \%40 eşik değerine göre; A ve B okulların yıkılması, C ve D okullarının ise güçlendirilmesine karar verilmesi gerekmektedir. 
Tablo 4. Örnek Olarak Seçilen Okullar Hakkında Yeni Yöntem Önerisine Göre İlk Aşama Karar Tablosu

\begin{tabular}{|c|c|c|c|c|}
\hline Okulun Özellikleri & A & B & C & D \\
\hline Bina Yaşı & 20 & 25 & 33 & 38 \\
\hline Mevcut Yapı İçin Tasarlanan Yapı Ömrü (YÖ) & 50 & 50 & 50 & 50 \\
\hline Güçlendirme Maliyeti (GM) (birim) & 41 & 48 & 38 & 27 \\
\hline Yeniden Yapım Maliyeti (YYM) (birim) & 100 & 100 & 100 & 100 \\
\hline Yapının Güncel Değeri (YGD) (birim) & 60 & 50 & 34 & 24 \\
\hline $\begin{array}{c}\text { Güçlendirme Maliyetinin Yeniden Yapım Maliyetine } \\
\text { Oranında Aşılmaması Gereken Değer (AGD) }\end{array}$ & $\begin{array}{c}0,60 \\
(\% 60)\end{array}$ & $\begin{array}{c}0,50 \\
(\% 50)\end{array}$ & $\begin{array}{c}0,34 \\
(\% 34)\end{array}$ & $\begin{array}{c}0,24 \\
(\% 24)\end{array}$ \\
\hline Güçlendirme Maliyeti / Yeniden Yapım Maliyeti & $\% 41$ & $\% 48$ & $\% 38$ & $\% 27$ \\
\hline İLK AŞAMA KARAR & $* *$ & $* *$ & $*$ & $*$ \\
\hline
\end{tabular}

* Binanın yıkımına karar verilebilir.

** Binanın güçlendirilmesine karar verilebilir.

Tablo 4'te ise yeni yöntem önerisine göre, sırasıyla 20,25, 33 ve 38 yaşındaki binalar için, "ilk aşamada" A ve B okullarının güçlendirilmesi, C ve D okullarının ise yıkılmasına karar verilmesi gerektiği görülmektedir.

Güçlendirme maliyetinin yeniden yapım maliyetine oranı sırasıyla \%41 ve \%48 olarak hesaplanan 20 ve 25 yaşlarındaki A ve B okul binalarının \%40 teamül değerinin üzerinde olmasına karşın yeni yöntemin ilk aşama kararına göre güçlendirilmesi gerektiği, maliyet oranları \%38 ve \%27 olarak hesaplanan 33 ve 38 yaşlarındaki C ve D okul binalarının $\% 40$ teamül değerinin altında olmasına karşın yeni yönteme göre yıkılması gerektiği kararına ulaşılması bu durum için çarpıcı bir örnek oluşturmaktadır.

Yukarıda da belirtildiği üzere ilk aşamada yıkım kararı verilen C ve D okulları için ikinci aşama hesaplamaları yapılmayacak, A ve B okulları ile diğer aşamalara devam edilecektir.

Tablo 5. Örnek Olarak Seçilen Okullar Hakkında Yeni Yöntem Önerisine Göre İkinci Aşama Karar Tablosu

\begin{tabular}{|c|c|c|}
\hline Okulun Özellikleri & A & B \\
\hline Güçlendirme Maliyeti (GM) (birim) & 41 & 48 \\
\hline Toplam Zorunlu İmalat Maliyeti (ZiM) (birim) & 30 & 40 \\
\hline GM + ZIM & 71 & 88 \\
\hline Yeniden Yapım Maliyeti (YYM) (birim) & 100 & 100 \\
\hline (GM + ZiM) / YYM & $\mathbf{0 7 1}$ & $\% 88$ \\
\hline IKİNCİ AŞAMA KARAR & $* * *$ & $* * *$ \\
\hline
\end{tabular}

*** Bina güçlendirilebilir, aynı zamanda yönetmelik ve standartlar gereği yapılması gereken zorunlu imalatlar yapılabilir.

Tablo 5'te yönetmelik ve standartlar gereği toplam zorunlu imalat maliyetleri sırasıyla 30 ve 40 birim olan A ve B okulları gösterilmektedir. Her iki okul için; güçlendirme maliyeti ile zorunlu imalat maliyeti toplamının yeniden yapım maliyetine oranı $\% 71$ ve $\% 88$ hesaplanmıştır. Söz konusu oranlar, kuralda geçen \%100'den küçük olduğu için A ve B okullarının güçlendirilmelerinin ve zorunlu imalatların yapımının ikinci aşama için onaylanabilir sonucunu ortaya çıkarmaktadır.

Tablo 6. Örnek Olarak Seçilen Okullar Hakkinda Yeni Yöntem Önerisine Göre Üçüncü Aşama Karar Tablosu

\begin{tabular}{|c|c|c|}
\hline Okulun Özellikleri & $\mathbf{A}$ & B \\
\hline Derslik Sayıs1 & 16 & 16 \\
\hline Öğrenci Kapasitesi & 480 & 480 \\
\hline Mevcut/Yakın Gelecekteki Öğrenci Sayısı & 718 & 450 \\
\hline Derslik İhtiyacı & 8 & Yok \\
\hline Ek Derslik Maliyeti (EDM) & 66 & 0 \\
\hline Güçlendirme Maliyeti (GM) (birim) & 41 & 48 \\
\hline Toplam Zorunlu İmalat Maliyeti (ZIM) (birim) & 30 & 40 \\
\hline GM + ZIM + EDM & 137 & 88 \\
\hline$(\mathrm{GM}+\mathrm{ZIM}) / \mathrm{YYM}$ & $\% 71$ & $\% 88$ \\
\hline Ek Derslik İhtiyacının Karşılandığı Yeni Okul Yapımı (Yerine Koyma Maliyeti (YKM)) & 113 & 88 \\
\hline$(\mathrm{GM}+\mathrm{ZIM}+\mathrm{EDM}) / \mathrm{YKM}$ & $\% 121$ & -.-- \\
\hline ÜÇÜNCÜ AŞAMA KARAR & $* * * *$ & $* * *$ \\
\hline
\end{tabular}

**** Bina hakkında karar verilebilmesi için aynı hizmet bölgesindeki yeni yatırımlar incelenmeli.

İkinci aşama sonucunda güçlendirilmesine ve yönetmelik/standartlar gereği zorunlu imalatların yapılmasına karar verilen A ve B okullarının ek derslik ihtiyacının incelendiği üçüncü aşama Tablo 6'da gösterilmiş̧tir. B okulunun 480 öğrencilik (30 öğrenci x 16) kapasitesi mevcut/yakın gelecekteki öğrenci sayısı (450) için yeterli olduğundan ek derslik binasına ihtiyacı olmadığına karar verilmişsir.

A okulunda ise kapasitesine göre öğrenci sayısının (718) fazla olmasından dolayı 8 ek derslikli bir ek binaya ihtiyacı olduğu açıktır. Toplam inşaat alanı $3.544 \mathrm{~m}^{2}$ olan 8 derslikli bir okulun yapımı Tablo 2'deki maliyet oranlarına göre 66 birim olacaktır. 16 
derslikli A okulunun yıkılarak ek derslik ihtiyacının da karşılandığı 24 derslikli yeni bir okul 113 birim maliyete (YKM) yapılacaktır. A okulunun güçlendirme maliyeti, zorunlu imalatların maliyeti ve ek derslik binasının maliyeti 24 derslikli yeni okul yapım maliyetine oranlandığında \% 121 olarak hesaplanmıştır. Bu durumda A okulunun da yıkılarak yeni bir okul yapılmasının uygun olacağı düşünülmektedir. Ancak, yıkım için kesin karar alınmadan önce aynı hizmet bölgesinde yeni bir eğitim yatırım planı olup olmadığı incelenmelidir.

Örneğin aynı hizmet bölgesinde yakın gelecekte nüfus artışı, göç vb. nedenlerle 24 derslikli E Okulu planlaması olduğunu varsayalım. Tablo 2'ye göre: 16 derslikli okul maliyeti 100 birim kabul edildiğinde, 24 derslikli okul maliyeti 113 birim, 32 derslikli okul maliyeti ise 144 birim olacaktır. Yukarıda oluşabilecek olası toplam maliyet seçenekleri verilmişti. Buna göre:

1. A Okulu güçlendirilebilir, yönetmelik ve standartlarda belirtilen zorunlu imalatlar yapılabilir, 8 derslikli ek bina inşa edilebilir ve aynı hizmet bölgesinde 24 derslikli yeni okul binası $\left(\mathrm{YO}_{1}-113\right.$ birim maliyet) yapılabilir. Bu durumda toplam maliyet $\left(\Sigma \mathrm{M}_{1}\right)$;

$$
\begin{aligned}
& \Sigma \mathrm{M}_{1}=\mathrm{GM}+\mathrm{ZIM}+\mathrm{EDM}+\mathrm{YO}_{1} \mathrm{M} \\
& \Sigma \mathrm{M}_{1}=41+30+66+113 \\
& \Sigma \mathrm{M}_{1}=250 \text { birim maliyet olacaktır. }
\end{aligned}
$$

2. A Okulu güçlendirilebilir, yönetmelik ve standartlarda belirtilen zorunlu imalatlar yapılabilir, aynı hizmet bölgesinde yapılması planlanan 24 derslikli okul binası için ihtiyaç duyulan ek derslik sayısı eklenerek yeni okul binası (32 derslik) $\left(\mathrm{YO}_{2}-144\right.$ birim maliyet) yapılabilir. Bu durumda toplam maliyet $\left(\Sigma \mathrm{M}_{2}\right)$;

$$
\begin{aligned}
\Sigma \mathrm{M}_{2} & =\mathrm{GM}+\mathrm{ZIM}+\mathrm{YO}_{2} \mathrm{M} \\
\Sigma \mathrm{M}_{2} & =41+30+144 \\
\Sigma \mathrm{M}_{2} & =215 \text { birim maliyet olacaktır. }
\end{aligned}
$$

3. A Okulu yıkılabilir, ek derslik ihtiyacının da karşılandığı 24 derslikli yeni okul (yerine koyma maliyeti YKM $_{1}$ yapılabilir, aynı hizmet bölgesinde planlanan 24 derslikli yeni okul binası $\left(\mathrm{YO}_{1}\right)$ inşa edilebilir. Bu durumda toplam maliyet $\left(\Sigma \mathrm{M}_{3}\right)$;

$$
\begin{aligned}
& \Sigma \mathrm{M}_{3}=\mathrm{YKM}_{1}+\mathrm{YO}_{1} \mathrm{M} \\
& \Sigma \mathrm{M}_{3}=113+113 \\
& \Sigma \mathrm{M}_{3}=226 \text { birim maliyet olacaktır. }
\end{aligned}
$$

4. A Okulu yıkılabilir, A Okulunun bulunduğu arsa ile yeni yatırım planlanan arsalardan hangisi uygun ise onun üzerine tüm ihtiyacı karşılayacak tek bir okul (48 derslikli) $\left(\mathrm{YKM}_{2}\right)$ yapılabilir. (Millı̂ Eğitim Bakanlığı'nın tip proje listelerinde 48 derslikli okul bulunmadığından iki adet 24 derslikli okul maliyeti alınmıştır. Ayrıca, bodrum + zemin +3 normal kattan fazla okul yapımının özellikle öğrenci güvenliği açısından uygun olmamasından dolayı 48 derslikli bir okul yapımı geniş araziler gerektirdiğinden, özellikle arsa temininin zor olduğu büyükşehirlerde, bu olasıllğın uygulanması mümkün görülememektedir.) Bu durumda toplam maliyet $\left(\Sigma \mathrm{M}_{4}\right)$

$$
\begin{aligned}
\Sigma \mathrm{M}_{4} & =\mathrm{YKM}_{2} \\
\Sigma \mathrm{M}_{4} & =226 \text { birim maliyet olacaktır. }
\end{aligned}
$$

Yukarıda yapılan hesaplamalar doğrultusunda A Okulu için, ikinci olasılıkta toplam maliyeti 215 birim olarak hesaplanan en düşük maliyetli koşulların yerine getirilebileceğine karar verilebilir.

Yeni yöntem önerisine göre yapılan incelemeler tümüyle ekonomik değerlendirme niteliği taşımaktadır. Karar vericilerin yukarıda detayları verilen ve örneklendirilen ekonomik değerlendirme sonuçları dışında Mutlu A.H. (2015) tarafından yapılan çalışmada belirtilen diğer etkenleri de dikkate alması gerekmektedir.

$\mathrm{Bu}$ çalışmada, güçlendirme/yıkım karar sürecindeki her bina için sınırlı ve bazı durumlarda hatalı bir ekonomik değerlendirme aracı olarak görülen \%40'lık teamül değerinin yerine; yapının yaşı ile bağlantılı yıpranma payına göre belirlenen ekonomik değerini göz önüne alan, güncel yönetmelik ve standartlar kapsamında yapılması gereken zorunlu imalatları da değerlendirilebilen yeni bir yöntem oluşturulmuştur. Yeni yöntemin ilk iki aşamasının bina türündeki tüm yapılara uygulanabilir olması yöntemin kapsamını genişletmektedir. Ayrıca, yeni ekonomik değerlendirme yönteminin, çalışmada örnek olarak seçilen eğitim yapılarının yanında taşınmaz değerleme kapsamındaki diğer özel veya kamu kurumu binaları için uygulamaya açık olması tartışılmaya değer bulunmaktadır. 


\section{Sonuç}

Yeryüzünün en yüksek deprem riskine sahip bölgelerinden birinde olan ülkemizde, telafisi maalesef mümkün olmayan can kayıplarının yanında, önlenebilir maddi kayıpların yaşandığı çok sayıda depremin meydana geldiği bilinmektedir. Bu nedenle deprem sonrası oluşabilecek can ve mal kayıplarının azaltılması için yapılan mevcut binaların güçlendirilmesi veya yıkılarak yerine yenisinin yapılması büyük önem taşımaktadır.

Deprem güvenliği belirlenmiş bir binanın güçlendirilmesine veya yıkılmasına karar verirken yapılan ekonomik değerlendirme de deprem öncesi yaşanabilecek maddi kayıpları azaltmak açısından önemli görülmektedir.

$\mathrm{Bu}$ çalışmada ortaya konan yeni ekonomik değerlendirme yöntemiyle, deprem güvenliği belirlenmiş ve teknik açıdan güçlendirilmesinde sakınca görülmeyen herhangi bir yapının güçlendirilmesi ya da yıkılması hakkındaki ekonomik karar sürecine yeni bir bakış açısı getirilmeye çalışılmıştır.

Oluşturulan yeni yöntemin getirdiği avantajlar aşağıda sıralanmıştır.

- Sınırlı ve hatalı ekonomik değerlendirmeye neden olan her yaştaki bina için sabit $\% 40$ eşik değeri yerine, binanın güncel değeri üzerinden ekonomik değerlendirme yapılmıştır. Örnekte de görüldüğü üzere geleneksel yönteme göre yıkım ve güçlendirme kararı çıkan okullar yeni yöntemle değerlendirildiğinde tam tersi sonuçlarla karşılaşılmıştır.

- Güncel yönetmelik ve standartlar gereği yapılması gereken imalatlar göz önüne alınmadan \%40 teamül değeri kullanılarak güçlendirilmesine karar verilen bir binada sonradan ekstra maliyetle karşılaşma riski bu yöntemle birlikte ortadan kalkmış olacaktır.

- Yöntemin ilk iki aşaması bina türü tüm yapılar için geçerli olduğundan yöntemin uygulanabilirlik kapsamı genişlemiştir.

- Yöntemin, çalışmada örnek olarak seçilen eğitim yapılarının yanında taşınmaz değerlemesi yapılabilen diğer özel veya kamu kurumu binaları için de geliştirilebilir olduğu belirlenmiştir.

- Yöntemde karmaşık matematiksel işlemler olmadığından ekonomik değerlendirmeye eklenmek istenen arsa değeri, kamulaştırma bedeli yıkım maliyeti gibi diğer bedellerin hesaplamaya dâhil edilmesi kolay olacaktır.

- Resmi verilere göre binlerce okul binası bulunan ve her geçen yıl buna yenileri eklenen eğitim yapıları yatırım planlarının da yeni yöntem kapsamında değerlendirilmesi, güçlendirme ve yıkım kararları ile eşgüdümlü olarak irdelenmesi, yatırım ödeneklerinin daha etkin, verimli ve ihtiyaca dönük kullanılmasını sağlayacaktır.

\section{Kaynakça}

[1] Z.G.Mülayim, Tarımsal Değer Biçme ve Bilirkişilik, Yetkin Yayınları, 2001, Ankara, s.5-12.

[2] H. Tanrıvermiş, Gayrimenkul Değerleme Esasları, Ders Kodu: 1014, Ankara, 2017.

[3] A. Üreten, Gayrimenkul Değerleme Yöntemleri ve Gayrimenkul Yatırım Ortaklıklarında Değer Tespiti, Yüksek Lisans Tezi, Gazi Üniversitesi Sosyal bilimler Enstitüsü, 2007, Ankara, s.25-26.

[4] A. Açlar ve V. Çağdaş, Taşınmaz (Gayrimenkul) Değerlemesi, İkinci Baskı, Ankara, Nisan 2008.

[5] Uluslararası Değerleme Standartları Konseyi, Uluslararası Değerleme Standartları, IVSC, 2017: UDS 105 Değerleme Yaklaşımları ve Yöntemleri 80.1.

[6] E. S. Ünalan vd., Genel Muhasebe, TDK Basımevi, Ankara, 1988.

[7] 213 Sayılı Vergi Usul Kanunu.

[8] FEMA, 9524.4 Repair vs. Replacement of a Facility Under 44 CFR §206.226(f) (The 50\% Rule), 2009.

[9] http://www.dask.gov.tr

[10]Tankut, T., Ersoy, E., Özcebe, G. ve Canbay, E., Betonarme Yapıların Onarımı ve Güçlendirilmesi İçin Kullanılan Yöntemler (Kitapta Bölüm), Bizim Büro Basımevi, Ankara, 2008.

[11]A. H. Mutlu, Mevcut Yapıların Güçlendirilmesi ya da Yıkılmasına Karar Verilmesi Aşamasında Göz Önüne Alınması Gereken Kriterler, 3. Türkiye Deprem Mühendisliği ve Sismoloji Konferansı, İzmir, 2015.

[12]M. Arıkan, H. Sucuoğlu, ve G. Macit, Economic assesment of these is mic-retrofitting of low-cost apartment buildings, Journal of Earthquake Engineering 9:4, 577-584, 2005.

[13]http://sgb.meb.gov.tr/www/resmi-istatistikler/icerik/64

[14]http://iedb.meb.gov.tr/www/bakanligimiza-ait-yeni-projeler/icerik/331 